\title{
How long can seeds of Norway spruce (Picea abies (L.) Karst.) be stored?
}

\author{
Bolesław SuSZKA $^{\mathrm{a} *}$, Paweł CHMIELARZ ${ }^{\mathrm{a}}$, Reinhard WALKENHORST ${ }^{\mathrm{b}}$ \\ a Polish Academy of Sciences, Institute of Dendrology, 62-035 Kórnik, Poland \\ bahnstraße 11, 63517 Rodenbach, Germany
}

(Received 16 July 2003; accepted 31 March 2004)

\begin{abstract}
Seeds of Norway spruce (Picea abies (L.) Karst.) belong to the orthodox category, because they can be desiccated to a low level of moisture content and be stored at low temperature without damage. Here we present original results of germination tests and observations of seedling development after storage of seeds for the first 17 years at $-5{ }^{\circ} \mathrm{C}$ to $-6^{\circ} \mathrm{C}$, followed by 12 years at $-3^{\circ} \mathrm{C}$, in total for 29 years at subfreezing temperatures. We also investigated cryopreservation in liquid nitrogen at $-196{ }^{\circ} \mathrm{C}$, as an alternative method of seed storage. Before cryopreservation, seeds were desiccated to a moisture content of 3 or $6 \%$. After 2-year storage in liquid nitrogen, their germination course and development of seedlings did not differ from those of freshly extracted and non-stored seeds and also from those of seeds stored for 2 years at $-3{ }^{\circ} \mathrm{C}$.
\end{abstract}

Picea abies / conservation / cryopreservation / desiccation / germination / seedling growth

Résumé - Combien de temps les graines d'épicea (Picea abies (L.) Karst.) peuvent-elles être conservées ? Les graines d'épicea appartiennent à la catégorie des graines dites orthodoxes parce qu'elles peuvent être déshydratées jusqu'à une faible teneur en eau et peuvent être conservées sans dommage à basse température. Nous présentons ici les résultats des tests de germination et des observations sur le développement des semis après stockage des graines pendant 29 ans, de -5 à $-6^{\circ} \mathrm{C}$ pendant 17 ans, puis à $-3{ }^{\circ} \mathrm{C}$ pendant 12 ans. La cryoconservation dans l'azote liquide $\left(-196^{\circ} \mathrm{C}\right)$, une méthode alternative de stockage des graines, a aussi été étudiée. Avant leur cryoconservation, les graines ont été deshydratées jusqu'à une teneur en eau de $3 \%$ ou $6 \%$. Après 2 ans de stockage des graines dans l'azote liquide, le déroulement de leur germination et le développement de semis ne différent pas de ceux des graines fraîchement extraites et non stockées ni de ceux des graines conservées pendant 2 ans à $-3{ }^{\circ} \mathrm{C}$.

Picea abies / cryoconservation / dessication / germination / stockage / croissance des semis

\section{INTRODUCTION}

Seeds of Norway spruce (Picea abies (L.) Karst.) belong to the orthodox category [14], because they can be desiccated to a low level of moisture content (3-5\%) and be stored at low temperature without damage. Several authors reported on the possibility of desiccation of Norway spruce seeds to a low or very low level, even to a moisture content (m.c.) of 1.8\% [19] without significant loss of viability. After desiccation, they can be stored in sealed containers for over 15 years at a temperature of $4{ }^{\circ} \mathrm{C}$ or, even more effectively, at a subfreezing temperature $[1,8,15,22]$. Norway spruce seeds tolerate even lower temperatures: $-70{ }^{\circ} \mathrm{C}[16],-75^{\circ} \mathrm{C}$ and $-196{ }^{\circ} \mathrm{C}$ [13]. For the latter two temperatures the results show no significant differences in viability of seeds after 15 months of storage in comparison with those seeds stored at $3{ }^{\circ} \mathrm{C}$ and $-25{ }^{\circ} \mathrm{C}$. Biochemical analyses of tissues of 9-day-old seedlings raised from seeds pretreated at $-75{ }^{\circ} \mathrm{C}$ revealed increased plasma membrane fluidity while its protein composition or ATP-ase activity did not change [13]. It was found [4] that seeds of orthodox species from the genera Abies, Alnus, Betula, Fraxinus, Larix, Picea, Pinus, after desiccation to a low m.c., can be stored without loss of viability for several years at subfreezing temperature.
Containers with the stored seeds should be tightly sealed [4, $21,22]$ to preserve the achieved low m.c. Anyway, extended storage of Norway spruce seeds at $4{ }^{\circ} \mathrm{C}$ causes, as its duration is extended, an increase in the number of chromosome aberrations and abnormal cell divisions in the tissues of roots of germinating seeds [17].

The m.c. of seeds freshly extracted from cones in modern extraction facilities is $5-6 \%$ and such seeds are for practical purposes stored in sealed containers at low temperature, usually ranging from $-3{ }^{\circ} \mathrm{C}$ to $-10{ }^{\circ} \mathrm{C}$. In the Polish Forest Gene Bank Kostrzyca, seeds of Norway spruce are stored at $-20^{\circ} \mathrm{C}$.

Seeds of Norway spruce with 8-18\% m.c. tolerate, without any damage, storage in liquid nitrogen for $5 \mathrm{~min}$ [24], seeds with a lower m.c. were not used in those investigations. Successful cryopreservation of Norway spruce seeds for $24 \mathrm{~h}$ [10] and for 6 days [3] was reported. Results of 2-year cryopreservation were published in 1998 as a short research note, where only partial results of the investigations were presented [6]. Not only zygotic embryos but also somatic embryos of Norway spruce can be desiccated and stored in liquid nitrogen [7], but there are still too many obstacles to introduce this technique (production of synthetic seeds $=$ encapsulated somatic embryos) into gene bank storage and reforestation [5].

*Corresponding author: suszkab@rose.man.poznan.pl 
Table I. Picea abies (L.) Karst., provenance Hochsauerland. Seed moisture content and results of germination tests in the Jacobsen tank of seeds stored initially at $-5{ }^{\circ} \mathrm{C}$ to $-6^{\circ} \mathrm{C}$, but later (from the 17 th to the 29 th year) at $-3{ }^{\circ} \mathrm{C}$.

\begin{tabular}{|c|c|c|c|c|c|c|c|c|}
\hline \multirow[t]{2}{*}{ Year } & \multirow{2}{*}{$\begin{array}{c}\text { Age } \\
\text { of seeds } \\
\text { (years) }\end{array}$} & \multirow{2}{*}{$\begin{array}{c}\text { Seed } \\
\text { moisture } \\
\text { content } \%\end{array}$} & \multicolumn{3}{|c|}{ Seed germination } & \multirow{2}{*}{$\begin{array}{c}\text { Dead } \\
\text { seeds } \\
\%\end{array}$} & \multirow{2}{*}{$\begin{array}{c}\text { Empty } \\
\text { seeds } \\
\%\end{array}$} & \multirow{2}{*}{$\begin{array}{c}\text { Abnormal } \\
\text { germination } \\
\%\end{array}$} \\
\hline & & & $\begin{array}{c}\text { Energy (7 days) } \\
\%\end{array}$ & $\begin{array}{c}\text { Capacity (14 days) } \\
\%\end{array}$ & $\begin{array}{l}\text { Mean germ. } \\
\text { time (days) }\end{array}$ & & & \\
\hline 1981 & 8 & - & - & $98.0^{*}$ & - & - & - & - \\
\hline 1984 & 11 & - & - & $96.0 *$ & - & - & - & - \\
\hline 1987 & 14 & - & - & $92.0 *$ & - & - & - & - \\
\hline 1988 & 15 & - & - & $92.0^{*}$ & - & - & - & - \\
\hline 1989 & 16 & - & - & $89.0^{*}$ & - & - & - & - \\
\hline 1990 & 17 & 5.8 & $\begin{array}{c}81.0^{\mathrm{a} * *} \\
(9.02)^{* * *}\end{array}$ & $\begin{array}{l}88.0^{\mathrm{b}} \\
(7.12)\end{array}$ & 6.6 & $\begin{array}{l}10.5^{\mathrm{c}} \\
(5.0)\end{array}$ & 1.0 & 0.5 \\
\hline 1995 & 22 & 10.2 & $\begin{array}{l}75.5^{\mathrm{a}} \\
(5.26)\end{array}$ & $\begin{array}{l}88.0^{\mathrm{b}} \\
(4.32)\end{array}$ & 6.4 & $\begin{array}{r}9.0^{\mathrm{c}} \\
(2.58)\end{array}$ & 1.0 & 2.0 \\
\hline 2002 & 29 & 10.3 & $\begin{array}{l}68.5^{\mathrm{a}} \\
(7.55)\end{array}$ & $\begin{array}{l}83.0^{\mathrm{b}} \\
(6.22)\end{array}$ & 6.6 & $\begin{array}{l}16.0^{\mathrm{c}} \\
(5.89)\end{array}$ & 0.5 & 0.5 \\
\hline
\end{tabular}

* Not included into the statistical analysis.

** Means indicated by the same letter within the same column, are not significantly different at $P \leq 0.05$ (ANOVA and Tukey's test).

*** Standard deviation (SD) in brackets.

Successful cryopreservation of air-dry seeds of other coniferous species has also been reported.

The aim of this study was to compare the classic method of cold long-term storage of Norway spruce seeds desiccated to a low m.c. with cryopreservation, presumably assuring preservation of seed viability over much longer periods. An important aim was also to gain information about the growth of seedlings after storage of seeds, the latter being a decisive criterion of the usefulness of any seed storage method.

\section{MATERIALS AND METHODS}

\subsection{Storage of seeds in traditional cold-stores}

Norway spruce cones of the non-autochthonous provenance Hochsauerland (Germany) were collected in 1973 and the seeds were extracted from them in the extraction plant Wolfgang in Hessia. After cleaning, dewinging and drying, the seeds were stored there in sealed containers at a temperature of $-5^{\circ} \mathrm{C}$ to $-6{ }^{\circ} \mathrm{C}$ from 1973 until 1990 , i.e. for 17 years. After 8 years of storage at these conditions their germinative capacity tested in Wolfgang was $98 \%$, while after the next 8 years (i.e. 16 years of storage) it decreased to $89 \%$ (Tab. I).

In February 1990, a part of this seed lot was sent from the Wolfgang seed extraction plant to the Institute of Dendrology in Kórnik (Poland) where its storage was continued. The seeds were sent to Poland by post in a sealed polyethylene bag, to be tested here immediately after arrival. It was found that the germinative capacity levels before and after transport did not change (Tab. I). In Kórnik, storage of these seeds was continued at $-3{ }^{\circ} \mathrm{C}\left( \pm 1{ }^{\circ} \mathrm{C}\right)$ for 12 years, i.e. until 2002 , so the seeds were stored for a total of 29 years. Because of the limited number of seeds, they were stored in one polyethylene bag. When these seeds were used for testing their viability, the bag was opened in the cold-store and after pouring off the necessary number of seeds it was immediately sealed again.

In Kórnik the seeds were used for germination tests $(4 \times 50$ seeds for each variant) in the Jacobsen germination tank and for the determination of their moisture content (fresh weight basis, oven drying, $24 \mathrm{~h}$ at $105^{\circ} \mathrm{C}$ [20].) In the last 12 years, the tests were conducted 3 times after 17, 22 and 29 years of storage (Tab. I). The germination tests were continued until the end of germination, usually not longer than for 14 days. The first count (called earlier germinative energy) was conducted after 7 days of the germination test $[9,23]$. In accordance with an earlier study [20], we applied a cyclically alternating temperature $23{ }^{\circ} \mathrm{C} \sim 27^{\circ} \mathrm{C}$ with the warmer phase lasting $2 \mathrm{~h}$ in every $24-\mathrm{h}$ period and with an increase and decline in temperature from and to the $23{ }^{\circ} \mathrm{C}$ level lasting $60-90 \mathrm{~min}$. For the calculation of mean germination time the formula [21] was applied

$$
\text { Mean germ. time }=\frac{l_{1} d_{1}+l_{2} d_{2}+\ldots l_{n} d_{n}}{l_{1}+l_{2}+\ldots l_{n}}
$$

where $d_{1}, d_{2} \ldots d_{n}=$ number of days counted from the start of the germination test $l_{1}, l_{2} \ldots l_{n}=$ number of seeds germinating on those days.

It was proved $[2,11,12]$ that light is necessary for better germination of Norway spruce seeds, because of the effect of the light-sensing mechanism, that regulates germination of seeds, so the tests were performed under a $16 \mathrm{~h}$ light $/ 8 \mathrm{~h}$ dark photoperiod with a $52 \mu \mathrm{mol} \mathrm{m} \mathrm{m}^{-2} \cdot \mathrm{s}^{-1}$ light (PPFD - Photosynthetic Photon Flux Density at the level of filter paper under the bell jars, $40 \mathrm{~W}$ Daylight, Polam, 380-680 nm). The period with temperature higher than $23{ }^{\circ} \mathrm{C}$ was included in the illumination time. The fluorescent tubes were placed $85 \mathrm{~cm}$ above the level of the filter paper.

Seeds with the radicle at least $3 \mathrm{~mm}$ long (criterion of germination) were removed from the filter paper and placed immediately on the surface of moist perlite for observation of their further development. Seeds containing decomposed or discoloured tissues were defined as dead ones while those without any content as empty seeds. The box with perlite covered with a transparent lid was placed in the Jacobsen tank at the same level as the germinating seeds in the same conditions of temperature and light.

Statistical analyses were carried out using STATISTICA software (Stat Soft Poland, version 5.1 M). Four 50-seed replications were randomly taken after each duration and type of storage to estimate the variation of germinative energy, germinative capacity [20,23] and percentage of dead seeds after storage. The means calculated for these parameters were evaluated by separate analyses of variance (ANOVA) followed by comparisons according to Tukey's tests significant at $P \leq 0.05$. Transformed data (arc-sin) were used for these analyses.

\subsection{Cryopreservation of seeds}

For storage in liquid nitrogen $\left(-196^{\circ} \mathrm{C}\right)$, we used seeds of three Polish provenances of Norway spruce: Midęzyzdroje, Węgierska Górka and Gołdap collected from about 100, 300 and 500 trees, respectively. 


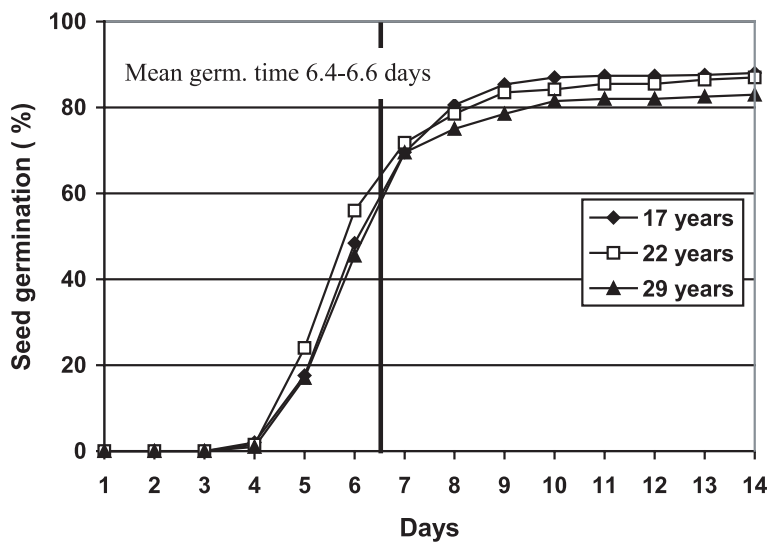

Figure 1. Picea abies (L.) Karst. provenance Hochsauerland. Germination course in the Jacobsen tank of seeds stored for 29 years (17 years at $-5^{\circ} \mathrm{C}$ to $-6^{\circ} \mathrm{C}$ followed by 12 years at $-3{ }^{\circ} \mathrm{C}$ ). The initial moisture content of seeds was $5.8 \%$.

All seeds of trees representing one provenance were combined into one seed lot. The seeds were extracted from cones in the Jarocin (Poland) extraction plant. In Kórnik they were dewinged, immediately subjected to moisture content assessment, cutting test, and germination test, and the remaining seeds were next desiccated above silica gel to two levels of m.c.; $3.0-3.5 \%$ and $6.2-6.6 \%$. Nearly all seeds (98-100\%) taken for the experiments were full. Their m.c. was determined before and after storage in relation to fresh weight in a Thermo Control Infrared Dryer $\left(120^{\circ} \mathrm{C} / 20 \mathrm{~min}\right.$ - the equipment was calibrated with the traditional oven method of drying to constant weight) for 3 replicates of 100 seeds each. For both m.c. and all the three provenances lots of 300 seeds were placed in separate $3.6 \mathrm{~mL}$ cryovials (Nunc) sealed afterwards and additionally wrapped tightly in a cryoflex sleeve (Nunc). Cryovials and cryoflex sleeves protected the seeds effectively against any water loss (the m.c. of seeds was determined before and after storage, and no changes in m.c. were observed). The cryovials with seeds were instantly immersed in liquid nitrogen. Germination tests and seedling observations were carried out on non-stored seeds $(0 \mathrm{~h}$, control) and stored seeds, after $1 \mathrm{~h}$ and 6, 12 and 24 months of cryopreservation. For each test the seeds still in the cryovials were thawed in warm water at $40{ }^{\circ} \mathrm{C}$ for $15 \mathrm{~min}$, and afterwards were sown (as dry seeds) on the surface of moist filter paper under bell jars in the Jacobsen tank.

For further observations, germinated seeds were planted into the boxes with moist perlite and placed in the Jacobsen tank at the same level as the germinating seeds, in the same conditions of temperature and light.

Seeds from 5 individual trees (age 130 years) belonging to the Gołdap provenance were extracted from cones in Kórnik, dewinged and desiccated to $6 \%$ m.c. to be used for a separate experiment on the effect of cryopreservation on seeds originating from various mother trees. The seeds were not stored $(0 \mathrm{~h}$, control $)$ or stored separately at $-3{ }^{\circ} \mathrm{C}$ or in liquid nitrogen, for $1 \mathrm{~h}$ or for 12 months. Germination tests and observations of seedling development were performed in the same conditions as those described above.

\section{RESULTS}

Seeds of Norway spruce, stored in sealed containers at temperatures ranging between $-3{ }^{\circ} \mathrm{C}$ and $-6{ }^{\circ} \mathrm{C}$ germinated vigorously and developed into normal seedlings even after storage lasting 29 years. Germination observed in Kórnik, always started on day 4 of the test and finished on day 14 (Fig. 1). Germinative capacity decreased by only $5 \%$ (differences not statistically significant) in the last 12 years of storage, while in the total period of 29 years it fell by $15 \%$. Mean germination time of seeds stored

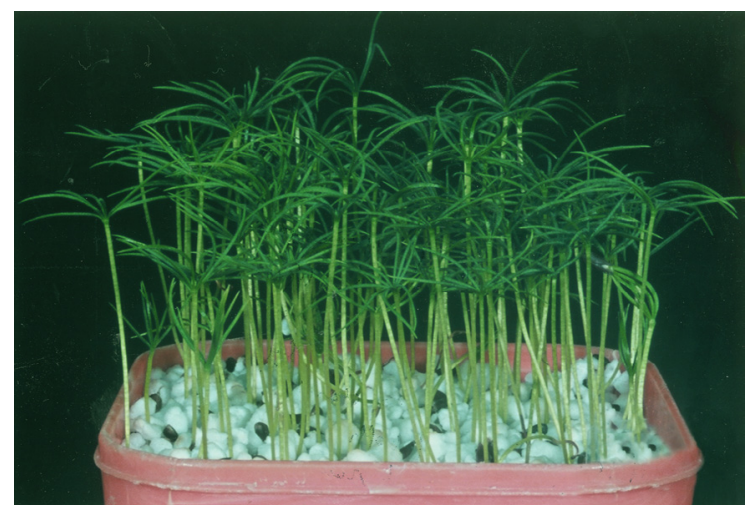

Figure 2. Picea abies (L.) Karst. provenance Hochsauerland. Seedlings developed from seeds stored for 29 years ( 17 years at $-5^{\circ} \mathrm{C}$ to $-6^{\circ} \mathrm{C}$, followed by 12 years at $-3^{\circ} \mathrm{C}$ ).

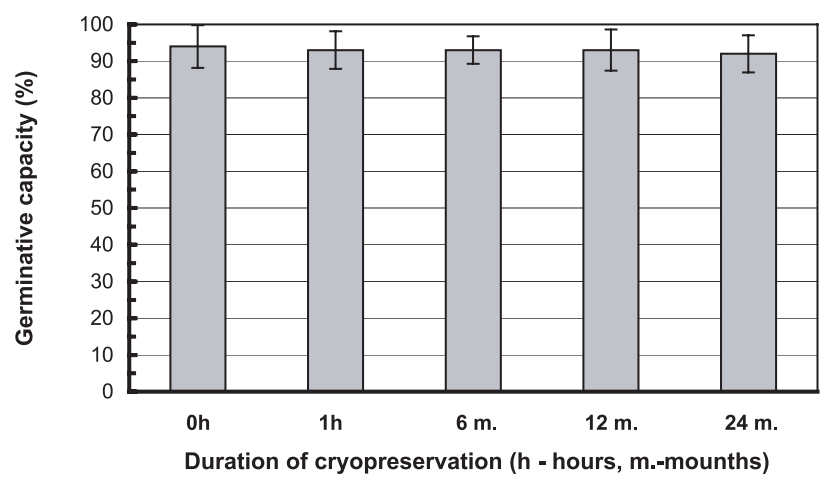

Figure 3. Picea abies (L.) Karst. Germinative capacity of seeds after storage in liquid nitrogen $\left(-196{ }^{\circ} \mathrm{C}\right)$ for $0 \mathrm{~h}$ (control), $1 \mathrm{~h}$, and for 6 , 12 and 24 months. The height of the bars represents mean values $( \pm \mathrm{SD}$ ) calculated for 3 provenances (Międzyzdroje, Węgierska Górka and Gołdap) of the seed material desiccated to an initial moisture content of $3 \%$ and $6 \%$.

for 17, 22 and 29 years did not change, always ranging between 6.4 6.6 days. Results of germination tests are presented in Table I.

Seeds germinating after 29 years of storage when placed in perlite continued the growth of the root, the hypocotyl elongated, the seed coat together with the megagametophyte dropped off, while the cotyledons developed and spread out, turning intensively green (Fig. 2).

It should be pointed out that the packing (bag) was opened repeatedly during storage, causing an increase in the seed m.c. from $5.8 \%$ after 17 years of storage to $10.3 \%$ after 29 years. However, another reason for the increase of seed m.c. could be also some absorption of water through the bag or accumulation of water as a product of seed metabolism (seed respiration) during extended storage. It seemed probable that the temperature of storage influenced more strongly and in a positive way the retaining of seed viability and vigour than their repeated contact with the moist air, which increased their m.c. to the value showed above.

Even after 2 years of storage in liquid nitrogen, a very high percentage of deeply dried seeds from mixed lots germinated. The germination rate for seeds of all provenances tested was not lower than that obtained for not stored seeds and after storage for two years at $-3{ }^{\circ} \mathrm{C}$, reaching 92-93\% (Figs. 3 and 4). 

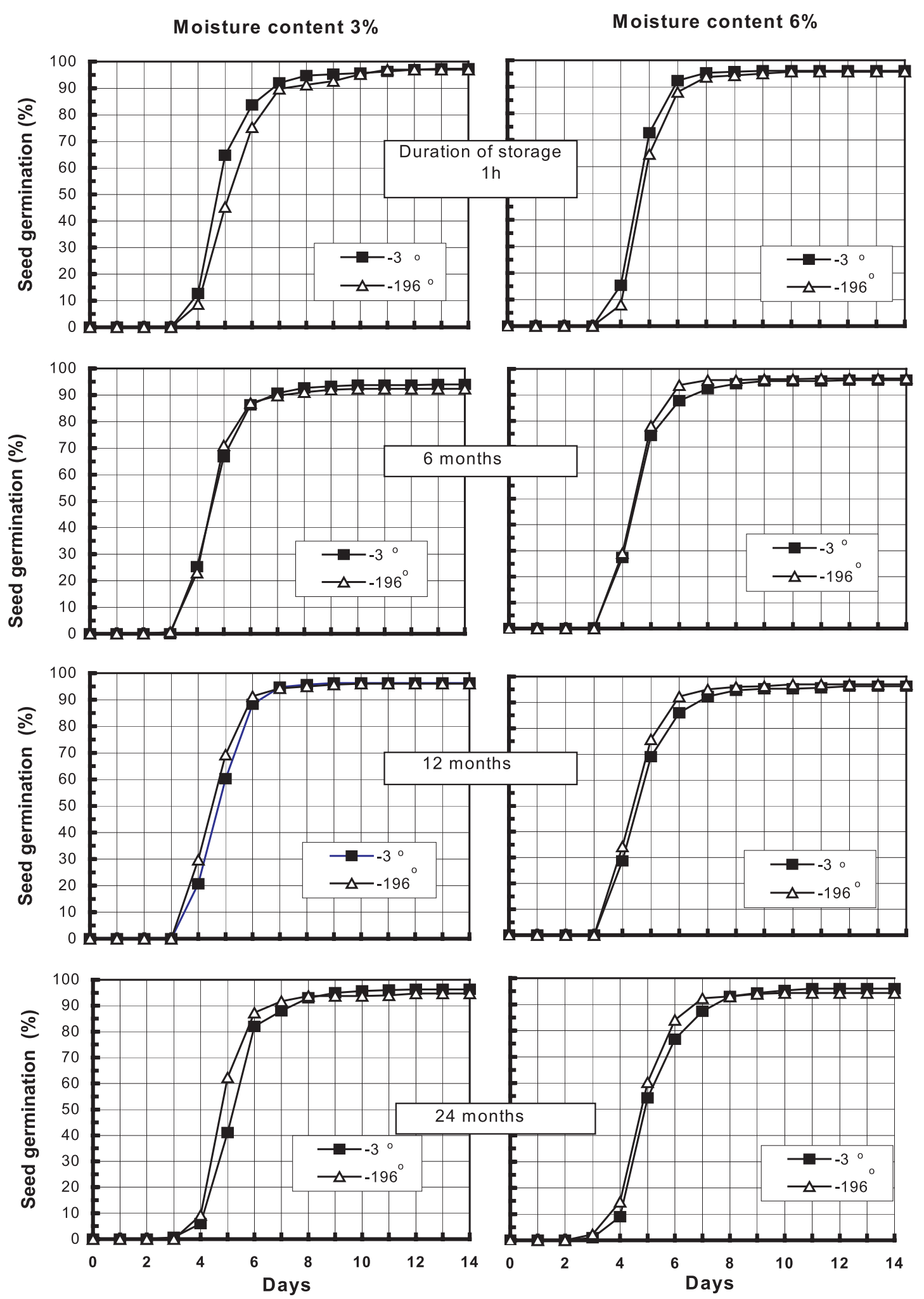

Figure 4. Picea abies (L.) Karst. provenance Gołdap. Germination course in the Jacobsen tank of seeds desiccated to $3 \%$ and $6 \%$ moisture content, stored in liquid nitrogen $\left(-196^{\circ} \mathrm{C}\right)$ for $0 \mathrm{~h}$ (control), $1 \mathrm{~h}$, and 6,12 and 24 months. 


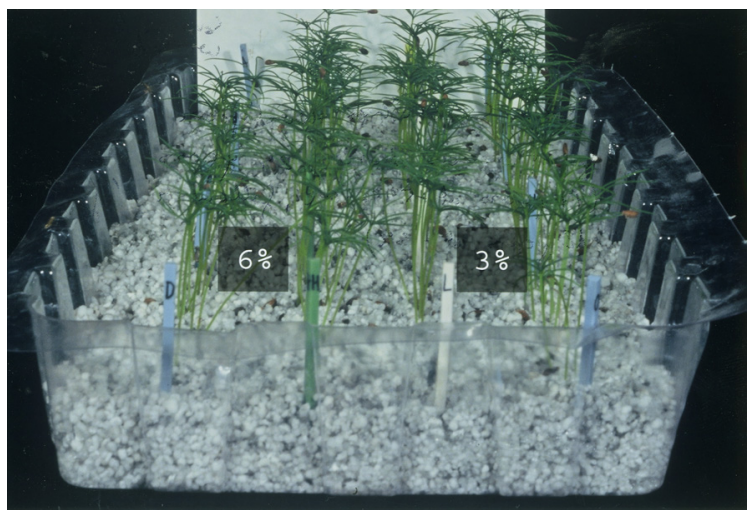

Figure 5. Picea abies (L.) Karst. provenance Gołdap. Seedlings developed from seeds stored in liquid nitrogen $\left(-196{ }^{\circ} \mathrm{C}\right)$ for 6 months. Storage was preceded by dehydration of seeds to $3 \%$ (both right rows) or $6 \%$ (both left rows).

Their germinative energy and capacity were high and after cryopreservation the seedlings developed normally (Fig. 5). The reaction of seeds from individual mother trees was similar (Fig. 6).

\section{DISCUSSION AND CONCLUSIONS}

The presented results indicate that a high viability and vigour (germinative capacity $83.0-98.0 \%$ ) of Norway spruce seeds, initially dehydrated to a m.c. of at most $5.8 \%$, can be retained for at least 29 years. However, it should be pointed out that during storage and the repeated opening of the package the m.c. of seeds increased gradually to $10.3 \%$ in the last 12 years.

Norway spruce seeds can be stored for practical purposes or in gene banks at a temperature not higher than $-3{ }^{\circ} \mathrm{C}$. During storage the containers should be tightly sealed and never opened before the end of storage. Seed moisture content and temperature of storage should be the lower, the longer is the planned storage period. In gene banks, like in the Forest Gene Bank Kostrzyca, the temperature of $-20^{\circ} \mathrm{C}$ is applied. This classic method will retain its usefulness for storage of seeds in cold-stores for practical purposes.

An alternative method, applicable only in much better equipped forest gene banks, is the cryopreservation of seeds in liquid nitrogen, started after dehydration of seeds to a level of either 3 or $6 \%$, but perhaps even higher, up to $18 \%$ [24].

Because of the time factor such investigations should be continued with the use of seeds at various levels of moisture content but artificially aged. We can expect, however, that the duration of cryopreservation of Norway spruce seeds can be considerably extended over that normally practised at present.

Acknowledgements: We thank Mrs Elżbieta Drzewiecka-Pieniężna for providing technical assistance during the experiments in Kórnik. Partial financial support from the State Committee for Scientific Research, Poland, grant No. SP06M 020 08, is also gratefully acknowledged.

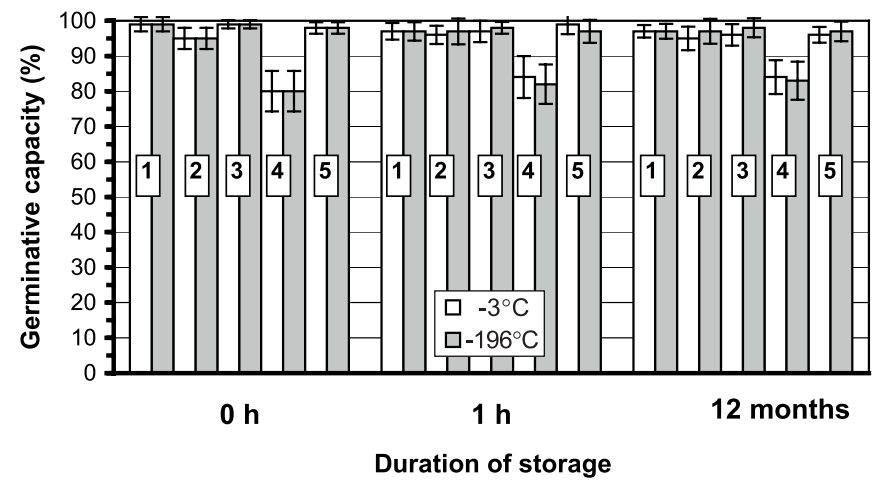

Figure 6. Picea abies (L.) Karst. provenance Gołdap. Germinative capacity $( \pm$ SD) in the Jacobsen tank of seeds from 5 individual trees (numbers $1-5$ ) stored at $6 \%$ moisture content for $0 \mathrm{~h}$ (control) and $1 \mathrm{~h}$, and for 12 months at $-3{ }^{\circ} \mathrm{C}$ or in liquid nitrogen at $-196{ }^{\circ} \mathrm{C}$.

\section{REFERENCES}

[1] Ahola V.K., The duration of germinability in pine and spruce seed, Metsät. Aikak. 2/3 (1951) 47-48.

[2] Ahola V., Leinonen K., Responses of Betula pendula, Picea abies and Pinus sylvestris seeds to red/far-red ratios as affected by moist chilling and germination temperature, Can. J. For. Res. 29 (1999) $1709-1717$.

[3] Ahuja M.R., Storage of forest tree germplasm in liquid nitrogen $\left(-196{ }^{\circ} \mathrm{C}\right)$, Silvae Genet. 35 (1986) 249-251.

[4] Bonner F.T., Storage of seeds: potential and limitations for germplasm conservation, For. Ecol. Manage. 35 (1990) 316-320.

[5] Bornman C.H., Somatic seed in conifer biotechnology - a viable alternative to natural seed? S. Afr. J. Bot. 68 (2002) 119-126.

[6] Chmielarz P., Cryopreservation of Norway spruce Picea abies (L.) Karst. seeds for two years (Research note), Plant Var. Seeds 11 (1998) 129-130.

[7] Gorbatenko O., Hakman I., Desiccation-tolerant somatic embryos of Norway spruce (Picea abies) can be produced in liquid cultures and regenerated into plantlets, Int. J. Plant Sci. 162 (2001) 12111218.

[8] Heit C.E., Propagation from seed. Part 10: Storage methods for conifer seeds, Am. Nurseryman, October 15, 1967, pp. 1-5.

[9] International rules for seed testing, Seed Sci. Technol. 13 (1985).

[10] Jörgensen J., Conservation of valuable gene resources by cryopreservation in some forest tree species, J. Plant Physiol. 136 (1990) 373-376.

[11] Leinonen K., Changes in dormancy and vigor of Picea abies seeds during overwintering and dry storage, Can. J. For. Res. 27 (1997) $1357-1366$.

[12] Leinonen K., De Chantal M., Regulation of Picea abies seed dormancy by red and far-red light at various moisture contents, Scand. J. For. Res. 13 (1998) 43-49.

[13] Rakowski K.J., Behzadipour M., Ratajczak R., Kluge M., Effect of seed freezing and storage conditions on plasma membrane properties of Norway spruce (Picea abies (L.) Karst.) seedlings, Bot. Acta 111 (1998) 236-240.

[14] Roberts E.H., Predicting the storage life of seeds, Seed Sci. Technol. 1 (1973) 449-514. 
[15] Rohmeder E., Beiträge zur Keimungsphysiologie der Forstpflanzen [Contributions to the germination physiology of forest plants], BLV, München, 1951

[16] Schönborn v. A., Die Aufbewahrung des Saatgutes der Waldbäume [Storage of seeds of forest trees], BLV, München, 1964.

[17] Simak M., Gustafsson A., Chromosomenaberrationen in alternden Forstsamen [Chromosome Aberrations in Aging Forest Seed] Slov. Acad. Sci. Bratislava (1973) 233-242.

[18] Stanwood P.C., Bass L.N., Seed germplasm preservation using liquid nitrogen, Seed Sci. Technol. 9 (1981) 423.

[19] Surber E., Vacuum-freeze drying of spruce seed, Mittl. Schweiz. Anst. Forst. Versuchsw. (1967) 317-330.

[20] Tyszkiewicz S., Ocena nasion drzew [Testing tree seeds], Inst. Bad. Lasów Pastw. Rozprawy Sprawozdania A 45 (1939).
[21] Tyszkiewicz S., Nasiennictwo Leśne [Forest seeds], Inst. Bad. Leśnictwa, Seria D, No. 2, Warszawa, 1949.

[22] Vincent G., Die Lagerung von Saatgut in geschlossenen Gefäßen [Storage of seeds in sealed containers], Centrabl. Ges. Forstw. 75 (1958) 257-267.

[23] Załęski A., Aniśko E., Kantorowicz W., Sobczak H., Zasady i metodyka oceny nasion w Lasach Państwowych [Rules and methods of seed testing in the State Forests], Centrum Informacyjne Lasów Panstwowych, Warszawa, 2000.

[24] Zentsch W., Über den Einfluß von flussigem Stickstoff auf die Keimfähigkeit des Saatgutes von Pinus silvestris L., Picea abies (L.) Karst., Betula pendula Roth und Alnus glutinosa (L.) Gaertn. [The effect of liquid nitrogen on germinability of seeds of Pinus silvestris L., Picea abies (L.) Karst., Betula pendula Roth und Alnus glutinosa (L.) Gaertn.], Arch. Forstw. 16 (1967) 725-730. 